Tajdid: Jurnal Pemikiran Keislaman dan Kemanusiaan

Vol. 4 No. 2 Oktober 2020

\title{
PERBUATAN MELAWAN HUKUM DALAM KORUPSI PENGADAAN BARANG DAN JASA OLEH PEMERINTAH
}

\author{
Taufik \\ STKIP Taman Siswa Bima \\ Email: taufikputera548@gmail.com
}

\begin{abstract}
Abstrak:
Penelitian ini dilakukan untuk menganalisis beberapa hal antara lai; (1) Karakteristik Perbuatan Melawan Hukum Dalam Korupsi Pengadaan Barang dan Jasa oleh Pemerintah. (2) Bentuk Kesalahan Dalam Pengadaan Barang dan Jasa Oleh Pemerintah, Penelitian ini menggunakan penelitian hukum normatif. Metode yang digunakan adalah pendekatan perundang-undangan (statuta approach),Pendekatan konseptual (conceptual approach), pendekatan kasus (caseapproach). Hasil penelitian menunjukan bahwasanya; (1) Karakteristik perbuatan melawan hukum dalam korupsi pengadaan barang dan jasa adalah merupakan pelanggaran/perbuatan melawan hukum atas undang-undang secara formiil dan materiil, berdasarkan penjelasan Pasal 2 UU Nomor.31 Tahun 1999 Jo. UU Nomor. 20 Tahun 2001 tentang tindak pidana korupsi, bahwa tindak pidana korupsi bukan saja perbuatan melawan hukum dari segi formiil namun juga merupakan melawan hukum materiil, namun penjelasan Pasal 2 tersebut, sudah dibatalkan oleh MK. (2) Bentuk kesalahan dalam Pengadaan barang dan Jasa Pemerintah,terletak pada 3 (tiga) aspek yakni: 1. Aspek Hukum Administrasi, 2. Aspek Hukum Perdata dan Aspek Hukum Pidana.
\end{abstract}

Kata Kunci: Korupsi, Pengadaan Barang dan Jasa, Pemerintah.

\section{Pendahuluan}

7 indak pidana korupsi yang terjadi akhir-akhir ini merupakan suatu fenomena kejahatan yang dilakukan secara bersama-sama terutama dalam bentuk

L pengadaan barang dan Jasa pemerintah,yang menggerogoti dan menghambat pelaksanaan pembangunan nasional.Mengingat demikian besarnya akibat yang dapat ditimbulkan dan sifat berbahayanya tindak pidana korupasi, maka didalam kebijakan peraturan perundang-undangan (kebijakan legislatif), tindak pidana korupsi diberi perioritas khusus bila dibandingkan dengan tindak pidana khusus lainnya.Pasal 25 UU Nomor.31 tahun 1999 sebagaimana diubah dan ditambah dengan UU Nomor.20 tahun 2001 tentang perubahan atas UU Nomor. 31 tahun 1999 tentang Pemberantasan Tindak Pidana Korupsi, menentukan bahwa" penyidikan, penuntutan, dan pemeriksaan di sidang pengadilan dalam perkara tindak pidana korupsi harus 
Tajdid: Jurnal Pemikiran Keislaman dan Kemanusiaan

Vol. 4 No. 2 Oktober 2020

didahulukan dari perkara-perkara lainguna penyelesaian secepatnya“. ${ }^{1}$ Apabila pemerintah pusat dan daerah memerlukan pengadaan barang dan Jasa, tentu adaduakemungkinan peluang yang terbuka, pertama : membuat sendiri atau membeli, dengan kata lain bahwa pemerintah dapat mengadakannya sendiri berdasarkan ketentuan, pedoman atau makanisme atau yang berkaitan dengan pengadaan barang dan Jasa olehpemerintah. Kedua: pemerintah dapat mengadakan atau melaksanakannya melalui pihak sawasta atau rekanan, dengan tetap mengacu pada ketentuan atau pedoman pengadaan barang dan jasa, atau sesuai dengan perangkat peraturan perundang undangan yang berlaku.

Unsur melawan hukum dari pelaku tindak pidana korupsi sukaruntuk dibuktikan, karena seringkali adanya perbuatan-perbuatan yang dipandang oleh masyarakat sebagai tindak pidana korupsi namun tak terjangkau oleh maksud dan ketentuan didalam Undang-undang karena kerancuan penempatan unsur melawan hukum. Dalam kenyataannya suatu perbuatan yang dipandang tercela atau koruptif oleh masyarakat meskipun perbuatannya tidak melawan hukum secara formil selalu lolos dari jangkauan hukum karena kesulitan pembuktiannya.Disini sifat melawan hukum suatu perbuatan hanya ada dalam pengertian sempit saja, sehingga hanya sekedar membuktikan ada atau tidaknya perbuatan melawan hukum atau niat sesuai yang tertera pada Undang-undang secara normatif dari pelaku. ${ }^{2}$

Korupsimerupakan salah satu bentuk kejahatan atau tindak pidana, atau suatu perbuatan melawan hukum (wederrechtelijk) yang sudah menggelobal (globalCrime) melanda hampir seluruh negara di dunia,yang mengakibatkan terjadinya kerugian keuangan dan perekonomian negara yang cukup besar jumlahnya,sehingga diberbagai negara di dunia saat ini pula,sangat gencar dan konsen untuk melakukan "Pembasmian" istilah Robert Klitgard ${ }^{3}$,terhadap perilaku koruptif dengan melahirkan kebijakan-kebijakan formulasi hukum untuk menjerat para pelaku (koruptor). Saat ini,perbuatan melawan hukum atau tindak pidana korupsi menjadi topik perbincangan dan mendapat perhatian yang luas dari seluruh elemen masyarakat di dunia. Adapun mekanisme pengadaan barang dan jasa oleh pemerintah, Antara lain :

\footnotetext{
${ }^{1}$ H. Elwi Daniel, Korupsi: Konsep Tindak Pidan dan Pemberantasannya, (Cet. 2; Jakarta: PT RajaGrafindo Persada, 2012), 71.

${ }^{2}$ Fitriati :Penerapan Ajaran Sifat Melawan Hukum Materil Dalam Perundang-Undangan Tindak Pidana Korupsi Di Indonesia, Tesis Magister Ilmu Hukum UNAND.

${ }^{3}$ Jeremy Pope, Strategi Pemberantasan Korupsi Elemen Sistem Integritas Nasional, (Cet. 2; Jakarta, 2007), 287.
} 
Tajdid: Jurnal Pemikiran Keislaman dan Kemanusiaan

Vol. 4 No. 2 Oktober 2020

1. TAP MPR Nomor. XI/MPR/1998 tentang Peyelenggara Negara yang Bersih dari Korupsi, Kolusi dan Nepotisme.

2. Undang-undang Nomor. 28 tahun 1999 tentang Penyelenggara Negara Yang Bersih dari Korupsi, Kolusi,dan Nepotisme. Sebagai implementasi dari TAP MPR Nomor. XI/MPR/1998 tahun 1998 tentang Penyelenggara Negara Yang Bersih dari Koripsi, Kolusi dan Nepotisme.

3. Undang-undang Nomor.31 tahun 1999 tentang perubahan atas Undang-undang Nomor.3 tahun 1971 tentang Pemberantasan Tindak Pidana Pidana Korupsi.

4. Undang-undang Nomor. 20 tahun 2001 tentang Perubahan atas Undang-undang Nomor. 31 tahun 1999 tentang Pemberantasan Tindak Pidana Korupsi.

5. Undang-Undang Nomor. 30 tahun 2002 tentang Komisi Pemberantasan Tindak Pidana Korupsi (KPK).

6. Undang-undang Nomor. 43 tahun 2002 tentang Pengadilan Tindak Pidana Korupsi. ${ }^{4}$

7. Keputusan Presiden Nomor. 80 tahun 2003 tentang Pedoman Pelaksanaan Pengadaan Barang/Jasa Pemerintah;

8. Keputusan Presiden Nomor. 61 tentang Perubahan atas Keputusan Presiden Nomor. 80 tahun 2003 tentang Pedoman Pelaksanaan Pengadaan Barang/Jasa Pemerintah;

9. Peraraturan Presiden Nomor. 54 Tahun 2010 yang mencabut Keputusan Presiden Nomor. 80 Tahun 2003 tentang Pedoman Pelaksanaan Pengadaan Barang dan Jasa Pemerintah;

10. Peraturan Presiden Nomor. 35 Tahun 2011 tentang Perubahan Kesatu atas Peraturan Presiden Nomor. 54 tahun 2010 tentang Petunjuk Pelaksanaan Pengadaan Barang dan jasa Pemerintah;

11. Peraturan Presiden Nomor. 70 Tahun 2012 tentang perubahan Kedua atas Peraturan Presiden Nomor. 54 Tahun 2010 tentang Petunjuk Pelaksanaan Pengadaan Barang dan Jasa Pemerintah. ${ }^{5}$

Perbuatan melawan hukum dalam korupsi pengadaan barang dan jasapemerintah sebagaimana diatur, dalam Pasal 7, Pasal 12 huruf h UU Nomor.31 Tahun 1999 Junto UUNomor.20 Tahun 2001 tentang Pemberantasan Tindak Pidana

\footnotetext{
${ }^{4}$ Ibid.

${ }^{5}$ Amiruddin, Korupsi dalam Pengadaan barang dan Jasa Pemerintah, (Cet. 1; Yogyakarta: Genta Publishing, ,2010), 3-5
} 
Tajdid: Jurnal Pemikiran Keislaman dan Kemanusiaan

Vol. 4 No. 2 Oktober 2020

Korupsi, serta ketentuan Pengadaan Barang dan Jasa Pemerintah sebagaimana diatur dalam Keputusan Presiden Nomor.80 Tahun 2003 dan perubahannyatentang Pedoman Pelaksanaan Pengadaan Barang dan Jasa oleh Pemerintah, yang dicabut berdasarkanPeraturan Presiden Nomor. 54 tahun 2010, dan perubahannya, benarbenar dijalankan secara konsisten, terhadap mereka yang melanggar, tentu harus ditindak secara tegas oleh aparat penegak hukum, tanpa memandang status dan kedudukan sosial yang bersangkutan dengan tetap memegang teguh asas praduga tak bersalah.

Menurut peneliti bahwa kedua pola pengadaan barang dan jasa tersebut samasama memiliki peluang untuk terjadinya tindak pidana korupsi, baik bagi pemerintah dengan pola pengadaan sendiri, maupun dengan pola menggunakan rekanan atau pihak swasta dalam pengadaan barang dan jasa, sebab pola pengadaan sendiri oleh pemerintah melalui panitia terdapat bebarapa hal yang bisa timbul dan memiliki konsekuensi hukum, antara lain ; penyalahgunaan kewenangan, adanya peluang kesalahan adminstrasi yang dapat dimanipulasi oleh oknum tertentu. Begitu pula halnya denganpotensi korupsi yang dapat dilakukanoleh pihak swasta atau rekanan pemerintah, yakni : terjadinya kecurangan (perbuatan melawan hukum) yang dilakukan oleh pihak pemborong/rekanan dengan melanggar ketentuan Pasal 7 dan Pasal 12 h, Undang-undang Nomor. 31 tahun 1999 junto Undang-undang Nomor.20 tahun 2001 tentang pemberantasan Tindak Pidana Korupsi.Terhadap peluang terjadinya tindak pidana korupsi sebagaimana yang disebutkan di atas,Amiruddinmengelompokkannya sekurang-kurangnya 7 (tujuh) bentuk tindak pidana korupsi dalam Pengadaan Barang dan Jasa oleh Pemerintah,yakni :

1. Merugikan keuangan Negara dengan melawan hukum atau penyalahgunaan wewenang (Pasal 2 dan 3 UU PTPK);

2. Suap (Pasal 5, 6, 11, 12 huruf a, b, c ,d dan Pasal 13);

3. Penggelapan dalam jabatan (pasal 8 dan pasal 10);

4. Pemerasan (Pasal 12 huruf e, $\mathrm{f}, \mathrm{g}$ );

5. Perbuatan curang (Pasal 7 dan Pasal 12 huruf h);

6. Konflik kepentingandalam pengadaan (Pasal 12 huruf i)

7. Gratifikasi (Pasal 12B dan 12C). ${ }^{6}$

\footnotetext{
${ }^{6}$ Amiruddin, Korupsi Dalam Pengadaan Barang dan Jasa, (Cet. 1; Yogyakarta:L Genta Publishing, 2010), 71
} 
Tajdid: Jurnal Pemikiran Keislaman dan Kemanusiaan

Vol. 4 No. 2 Oktober 2020

Dalam menganalisis apakahterjadi suatu pelanggaran atau perbuatan melawan hukum (wederrechtelijkheid) dalam pengadaan barang dan jasa pemerintah, ada 3 bentuk atau aspek tolok ukur untuk menilainya yaitu :

1. Aspek hukum administrsidalam Pengadaan Barang dan Jasa;

2. Aspek hukum perdatadalam Pengadaan Barang dan Jasa dan ;

3. Aspek hukum pidana dalam Pengadaan Barang dan Jasa. ${ }^{7}$

\section{Metode Penelitian}

Jenis penelitian yang digunakan dalam penelitian ini adalah penelitian hukum Normatif atau disebut juga penelitian Doktrinal. Penggunaan jenis penelitian ini dikerana penelitian menganalis terkat dengan masalah perbuatan melawan hukum dalam korupsi pengadaan barang dan jasa oleh pemerintah dilihat dari sisi analisis hukumnya. Sehingga arah kajain penelitian lebih menekana pada penelaan teks peundang-undangan terkaita dengan perbutatan/tindakan pidana korupsi.

\section{Pembahasan}

\section{Karakteristik Perbuatan melawan Hukum Dalam Korupsi Pengadaan Barang dan Jasa Oleh Pemerintah}

\section{Sifat Perbuatan Melawan Hukum Materiil}

Pengertian melawan hukum dalam pandangan materiil adalah tidak saja perbuatan yang melanggar hukum tertulis, melainkan melanggar hukum tidak tertulis, sehingga dalam ilmu hukum, disebut dengan ajaran sifat melawan hukum materiil yaitu selain memenuhi semua unsur dalam rumusan delik perbuatan itu harus benarbenar dirasakan oleh masyarakat sebagai perbuatan yang tidak boleh atau tidak patut dilakukan. Menurut ajaran ini sifat melawan hukumnya perbuatan yang nyata-nyata telah diatur dalam undang-undang dapat hapus baik karena ketentuan undang-undang maupun aturan-aturan yang tidak tertulis.

Hal yang sama disampaikan oleh Indriyanto Seno Adji yang memberikan pandangan bahwa "perbuatan melawan hukum secara formil lebih menitik beratkan pada pelanggaran terhadap peraturan perundang-undangan yang tertulis, sedangkan suatu perbuatan dikatakan telah memenuhi unsur melawan hukum secara materil, apa bila perbuatan itu merupakan pelanggaran terhadap norma kesopanan yang lajim atau kepatutan yang hidup dalam masyarakat. Dengan kata lain, setiap perbuatan yang

\footnotetext{
${ }^{7}$ Ibid., $48-71$
} 
Tajdid: Jurnal Pemikiran Keislaman dan Kemanusiaan

Vol. 4 No. 2 Oktober 2020

dianggap atau dipandang tercela oleh masyarakat merupakan perbuatan melawan hukum secara materil. ${ }^{8}$ Sementara itu Vos dan Hulsman, yang pendapatnya diikuti oleh Jonkers dan Langemeyer, yang secara subtansial sama seperti apa yang disampaikan olehIndriyanto Seno Adji di atas, yang menyatakan :

"bahwa belum tentu kalau semua perbuatan yang mencocoki larangan undangundang bersifat melawan hukum, bagi tokoh ini yang dinamakan hukum bukanlah undang-undang saja, karena disamping undang-undamg (tertulis) ada pula hukum yang yidak tertulis, yaitu norma atau kenyataan yang berlaku dalam masyarakat," 9

2. Sifat Perbuatan Melawan Hukum formiil

Menurut pandangan hukum formil perbuatan melawan hukum (formalewederrechtelijkheid) lebih dititik beratkan pada pelanggaran terhadap peraturan perundang-undangan yang tertulis, pemahaman seperti ini bertolak dari asumsi dasar bahwa hukum adalah undang-undang, sebagaimana pendapat yang dikemukakan oleh Indriyanto seno Adji yang mengatakan: "bahwa perbuatan melawan hukum secara formil (formalewederrechtelijkheid) lebih dititik beratkan pada pelanggaran terhadap peraturan perundang-undangan secara tertulis..."10.

3. Perbuatan Melawan Hukum Materiil Dalam Fungsinya yang Negatif

Dalam tulisan Lobby loqman yang dikutip oleh Amiruddin menkonsepkan bahwa perbuatan melawan hukum materiil yang berfungsi negarif, adalah "apabila terdapat suatu perbuatan nyata-nyata merupakan perbuatan melawan hukum secara formiil, sedangkan di dalam masyarakt perbuatan tersebut tidak tercela, jadi secara materil tidak melawan hukum, perbuatan tersebut seyogianya tidak dijatuhi pidana." ${ }^{11}$ Hal senada juga dikemukakan oleh Oemar Seno Adji yang mengatakan bahwa:

"meskipun perbuatannya telah memenuhi rumusan deliknya, artinya secara formil perbuatannya adalah wederrechtelijk, namun si pelaku tidak dapat dipidana apabila perbuatannya adalah materiel tidak wederrechtelijk. Artinya, meskipun perbuatan terdakwa telah memenuhi unsur tindak pidana tertentu, apabila perbuatan tersebut menurut nilai-nilai yang hidup di masyarakat tidak lagi mengandung sifat melawan hukum, telah merupakan socialadaguat...(nilai

\footnotetext{
${ }^{8}$ Ibid ., 400

${ }^{9}$ Ibid., 401

${ }^{10}$ Ibid.

${ }^{11}$.Amiruddin....,45
} 
Tajdid: Jurnal Pemikiran Keislaman dan Kemanusiaan

Vol. 4 No. 2 Oktober 2020

sosial), telah menjadi hal yang biasa dalam masyarakat, maka kepada terdakwa tidak dipidana." 12

Berlakunya sifat melawan hukum material dalam fungsinya yang negatif, merupakan alasan peniadaan pidana di luar Undang-undang, dan termasuk alasan pembenar. ${ }^{13}$

1. Perbuatan Melawan Hukum Materiil Dalam Fungsinya yang Positif

Pengertian sifat melawan hukum secara materiil dalam artinya yang positif akan merupakan pelanggaran asas legalitas, pada Pasal 1 ayat 1 KUHP, artinya ajaran sifat melawan hukum dalam fungsi positif yaitu meskipun suatu perbuatan secara materiil merupakan perbuatan melawan hukum apabila tidak ada aturan tertulis dalam perundang-undangan pidana, perbuatan tersebut tidak dapat dipidana. ${ }^{14}$ Ajaran sifat melawan hukum materiil dalam fungsinya yang positif memberikan pandangan, bahwa suatu perbuatan tetap dianggap sebagai suatu delik atau tindak pidana, sekalipun perbuatan tersebut tidak secara eksplisit dirumuskan dan diancam dengan pidana dalam undang-undang, apabila perbuatan tersebut bertentangan dengan hukum atau ukuran-ukuran nilai yang berada di luar undangundang, seperti misalnya nilai kesusilaan, nilai agama dan sebagainya. Dengan pemahaman yang demikian maka ajaran sifat melawan hukum materiil dalam fungsinya yang positif mengakui hal yang berada di luar undang-undang.

2. Perbuatan Melawan Hukum Pasca Putusan MK Nomor. 003/PUU-IV/2006

Latar belakang lahirnya putusan MK Nomor. 003/PUU-IV/2006 atas uji materiel terhadap Pasal 2 ayat (1) UU PTPK adalah di ajukan oleh pemohon Ir. Dawud Jadmiko yang didakwa oleh Penuntut Umum dengan dakwaan Primair melanggar Pasal 2 ayat (1) jo. Pasal 18 ayat (1) huruf a,b UU PTPK jo. Pasal 55 ayat (1) ke-1 jo. Pasal 64 ayat (1) KUHP dan yang bersangkutan menganggap hak konstitusionalnya dirugikan karena berlakunya UU PTPK. Lebih lanjut terkait perbuatan melawan hukum, dijumpai dalam penjelasan umum UU Nomor. 31 tahun 1999 disebutkan: ${ }^{15}$

\footnotetext{
${ }^{12}$ Ibid

${ }^{13}$ Ibid

${ }^{14}$ Indiyanto Seno Adji...., 18

${ }^{15}$ Pejelasan Umum Undang-undang Nomor.31 tahun 1999 Jo UU Nomor. 20 tahun 2001 tentang pemberantasan tindak pidana korupsi
} 
Tajdid: Jurnal Pemikiran Keislaman dan Kemanusiaan

Vol. 4 No. 2 Oktober 2020

"agar dapat menjangkau modus operandi penyimpangan keuangan negara yang semakin canggih dan rumit, maka tindak pidana yang diatur dalam Undangundang ini dirumuskan sedemikian rupa sehingga meliputi perbuatan-perbuatan memperkaya diri sendiri atau orang lain atau suatu korporasi secara "melawan hukum" dalam pengertian formiel dan materiel. Dengan perumusan tersebut pengertian melawan hukum dalam tindak pidana korupsi dapat pula mencakup perbuatan-perbuatan tercela yang menurut keadilam masyarakat harus dituntut dan dipidana."

Menurut penulis, untuk mengukur perbuatan melawan hukum dalam tindak pidana korupsi, tentu harus bersandar pada perbuatan pelaku, baik perbuatan melawan hukum secara formil maupun perbuatan melawan hukum materiil, sebab jika hanya dipandang dari satu sisi saja, akan melahirkan suatu ketidak adilan dalam masyarakat, terlepas dari adanya alasan yang meniadakan pidana terhadap pelaku, oleh sebab itu penegak hukum dalam hal penerapan Pasal-pasal tentang tindak pidana korupsi harus benar-benar fokus sesuai dengan perbuatan atau kesalahan pelaku. Disatu sisi dengan penerapan keduanya, akan menabrak asas legalitas sebagai landalasan utama dalam hukum pidana kita (Indonesia), terkhusus perbuatan Pidana di luar KUHPidana.

\section{Bentuk Kesalahan Dalam Pengadaan barang dan Jasa Oleh Pemerintah}

1. Tanggung jawab Jabatan dalam Pengadaan Barang dan Jasa

Tanggung jawab jabatan berkenaan dengan legalitas (keabsahan) tindak pemerintahan.Dalam hukum administrasi, persoalan legaliatas tindak pemerintahan

berkaitan dengan pendekatan terhadap kekuasaan pemerintahan. ${ }^{16}$ Pendapat atau pandangan tersebut pada dasarnya sama dengan yang di kemukakan oleh Amiruddin, namun Amiruddin lebih merincinya dengan 3 (tiga) pendekatan yakni "wewenang, prosedur dan substansi." ${ }^{17}$ Yang dijelaskan sebagai berikut:

a. Wewenang

Setiap tindakan pejabat tidak terkecuali pula dalam pengadaan barang dan jasa, harus bertumpu pada kewenangan yang sah, yang mana kewenangan yang sah, yang harus diperoleh melalui 3 (tiga) sumber atau perosedur yang harus diikuti yakni : atribusi, delegasi dan mandat.

\footnotetext{
${ }^{16}$ Philipus M. Hadjon...., 16

${ }^{17}$ Amiruddin....,96
} 
Tajdid: Jurnal Pemikiran Keislaman dan Kemanusiaan

Vol. 4 No. 2 Oktober 2020

b. Wewenang Pejabat Pembuat Komitmen (PPK)

Pejabat Pembuat Komitmen (PPK) adalah pejabat yang bertanggung jawab terhadap pelaksanaan pengadaan barang dan jasa dan sekaligus sebagai pemilik pekerjaan. Disamping kewenangan di atas, PPK juga memiliki kewengan menetepkan besaran biaya pengadaan barang dan jasa sebagaimana dijelaskan dalam Pasal 26 huruf a Keppres Nomor. 80 Tahun 2003 tentang pedoman pengadaan barang dan jasa pemerintah:

"Pengguna barang/jasa untuk pengadaan yang bernilai sampai dengan Rp50.000.000.000,00 (lima puluh miliar rupiah) tanpa memerlukan persetujuan Menteri/Panglima TNI/Kepala Polri/Pemimpin Lembaga/Gubernur/Bupati/Walikota/Dewan Gubernur BI/Pemimpin BHMN/Direksi BUMN/BUMD, pejabat atasan pengguna barang/jasa yang bersangkutan".

c. Prosedur

Asas umum pengadaan barang dan jasa oleh pemerintah yakni berlandaskan pada ketentuan Pasal 3 Keppres Nomor. 80 Tahun 2003 jo Perpres Nomor. 95 Tahun 2007 tentang Petunjuk Pelaksanaan pengadaan barang dan jasa oleh pemerintah, wajib menetapkan prinsip-prinsip efisiensi, efektfi, transparan, akuntabel serta adil.

d. Substansi

Berdasarkan kewenangan yang tertuang dalam Pasal 17 ayat (2) UU Nomor. 1 Tahun 2004, tentang Perbendaharaan Negara, Kuasa Pengguna Anggaran berwenang "mengadakan perjanjian dengan pihak lain dalam batas anggaran yang telah ditentukan".

Berdasarkan uraian di atas, berkitan dengan bentuk kesalahan dalam pengadaan barang dan jasa oleh pemerintah, maka dapat dilihat melalui pelanggaran atas wewenang, prosedur dan substansi. Dengan demikian bentuk kesalahan dalam pengadaan barang dan jasa oleh pemerintah adalah terdapat 3 hal, yakni: 1). Bentuk kesalahan secara Hukum Administrasi, 2). Bentuk kesalahan secara hukum perdata dan 3. Bentuk kesalahan dalam hukum pidana.

\section{Tanggung jawab Pribadi dalam Pengadaan Barang dan Jasa}

Dalam kaitannya dengan penyelenggaraan pengadaan barang dan jasa oleh pemerintah, tidak terlepas adanya tanggung jawab pidana. Tanggung jawab pidana 
Tajdid: Jurnal Pemikiran Keislaman dan Kemanusiaan

Vol. 4 No. 2 Oktober 2020

adalah “...merupakan tanggung jawab pribadi" ${ }^{18}$, dengan demikian maka fokus tanggung jawab pribadi dalam pengadaan barang dan jasa oleh pemerintah adalah tindakan "maladinistrasi". Dengan demikian, berdasarkan rumusan maladministrasi di atas, maka bentuk-bentuk maladministrasi mencakup; perbuatan melawan hukum, melampaui wewenang, menggunakan wewenang untuk tujuan lain dari yang menjadi tujuan wewenang; dan kelalaian atau pengabaian kewajiban hukum dalam penyelenggaraan pelayanan publik. ${ }^{19}$

\section{Penutup}

Berdasarkan analisis uraian di atas terkait dengan Perbuatan Melawan Hukum dalam Korupsi Pengadaa Barang dan Jasa oleh Pemerintah dapat disimpulkan dua hal utama antara lain: (1)Karakteristik Perbuatan Melawan Hukum dalam Korupsi Pengadaa Barang dan Jasa oleh Pemerintah adalah merupakan perbuatan melawan hukum atas undang-undang secara formiil dan Materiil, berdasarkan penjelasan Pasal 2 ayat 1UU Nomor. 31 Tahun 1999 Jo. UU Nomor. 20 Tahun 2001 tentang tindak pidana korupsi. (2) Bentuk korupsi dalam Pengadaan barang dan Jasa Pemerintah,terletak pada 3 (tiga) Aspek yakni : 1. Aspek Hukum Administrasi, 2. Aspek Hukum Perdata dan Aspek Hukum Pidana.

\section{DAFTAR PUSTAKA}

Daniel, Elwi. Korupsi: Konsep Tindak PidanA dan Pemberantasannya. Cet. 2; Jakarta: PT. RajaGrafindo Persada, 2012.

Fitriati. Penerapan Ajaran Sifat Melawan Hukum Materil Dalam PerundangUndangan Tindak Pidana Korupsi Di Indonesia, Tesis Magister Ilmu Hukum UNAND.

Pope, Jeremy. Strategi Pemberantasan Korupsi Elemen Sistem Integritas Nasional, Cet. 2; Jakarta: PT. RajaGrafindo Persada, 2007.

Amiruddin. Korupsi dalam Pengadaan barang dan Jasa Pemerintah,Cet. 1; Yogyakarta: Genta Publishing,Yogyakarta, 2010.

Undang-undang Nomor.31 tahun 1999 Tentang Pemberantasan Tindak Pidana Korupsi.

Undang-undang Nomor 20 tahun 2001 tentang pemberantasan tindak pidana korupsi

\footnotetext{
${ }^{18}$ Philipus M. Hadjon et al.....,17

${ }^{19}$ Amiruddin....,117
} 